\title{
OPEN Author Correction: Artificial neural network analysis of the oxygen saturation signal enables accurate diagnostics of sleep apnea
}

\author{
Sami Nikkonen $(\mathbb{D}$, Isaac $\mathrm{O}$. Afara $\mathbb{D}$, Timo Leppänen \& Juha Töyräs \\ Correction to: Scientific Reports https://doi.org/10.1038/s41598-019-49330-7, published online 13 September \\ 2019 \\ This Article incorrectly states that informed consent was obtained. Consent for research was not sought, because \\ under Finnish law (Law on medical research $2 \$(23.4 .2004 / 295)$ ) the need for consent is not required for retro- \\ spective chart reviews.
}

\begin{abstract}
(c) (i) Open Access This article is licensed under a Creative Commons Attribution 4.0 International License, which permits use, sharing, adaptation, distribution and reproduction in any medium or format, as long as you give appropriate credit to the original author(s) and the source, provide a link to the Creative Commons license, and indicate if changes were made. The images or other third party material in this article are included in the article's Creative Commons license, unless indicated otherwise in a credit line to the material. If material is not included in the article's Creative Commons license and your intended use is not permitted by statutory regulation or exceeds the permitted use, you will need to obtain permission directly from the copyright holder. To view a copy of this license, visit http://creativecommons.org/licenses/by/4.0/.
\end{abstract}

(C) The Author(s) 2020 